\title{
Cleome hirta (Cleomaceae), an addition to Asia from Gujarat, India
}

\author{
M.R. Bhatt ${ }^{*}$, W. Arisdason ${ }^{2}$ and P.S. Nagar ${ }^{1}$ \\ 'Department of Botany, Faculty of Science, The Maharaja Sayajirao University of Baroda, \\ Vadodara, Gujarat - 390002, India. \\ ${ }^{2}$ Central National Herbarium, Botanical Survey of India, Botanic Garden P.O., Howrah - 711103, \\ West Bengal, India. \\ *E-mail: mitalbhatt1990@gmail.com
}

\begin{abstract}
Cleome hirta (Klotzsch) Oliv. (Cleomaceae), a species indigenous to tropical Africa is reported here as an addition to the angiospermic flora of Asia from Gujarat state, Western India. Detailed description, colour photographs, flowering and fruiting period, details on habitat, plant association and distrbution of the species are provided here.
\end{abstract}

Keywords: Cleomaceae, Cleome, Gujarat, New Record

\section{Introduction}

Cleome L. (Cleomaceae), a pantropical genus comprises 250-280 species (Sanchez-Acebo, 2005; Inda et al., 2008; Mabberley, 2008). In India, it is represented by 15 species and 2 varieties (Sundararaghavan, 1993), of which 9 species are distributed in Gujarat state (Santapau, 1962; Shah, 1978). During the floristic explorations in Gujarat state, a small population of a Cleome species was observed in Dabhoi taluka, Vadodara district, and a few specimens were collected from the existing population by first author for study. The collected voucher specimens are studied critically with literature and identified as C. hirta (Klotzsch) Oliv., a species indigenous to tropical Africa. The identification was further confirmed by matching the specimens with electronic images of herbarium specimens at Kew Herbarium Catalogue (http:// www.apps.kew.org). Hence, it is reported here as an addition to the flora of Asia with detailed description and colour photographs for its easy identification. The present report makes 10 species from the state of Gujarat and 16 species and 2 varieties of Cleome in India.

Cleome hirta (Klotzsch) Oliv. in Oliv. et al., Fl. Trop. Afr. 1: 81. 1868. Decastemon hirtus Klotzsch in Peters, Naturw. Reise Mossambique 6 (Bot., 1): 157. 1861.

Fig. 1

Undershrub, perennial, erect, 1.5-2 m high, branched. Stems terete, striated, $8.5-9 \mathrm{~cm}$ in diam., densely covered with glandular hairs. Leaves alternate, exstipulate, 5-9-foliolate; petioles 0.8-5.3 cm long, viscid, glandular, pubescent; leaflets linear to lanceolate, $1-3.7 \times 0.3-0.6 \mathrm{~cm}$, decreasing in size upwards and passing gradually into sessile bracts, cuneate at base, entire at margins with glandular hairs, subacute to rounded at apex; petiolules c. 1 $\mathrm{mm}$ long. Inflorescence a raceme, terminal with 50-60 flowers, initially dense but during fruiting it elongates greatly. Flowers 2.6-3.1 cm long, subtended by small, sessile 5-foliolate bracts; pedicels $1.5-1.8 \mathrm{~cm}$ long, covered with glandular hairs. Sepals 4, linear, $0.8-1 \times c .0 .1 \mathrm{~cm}$, acute at apex, glandular, pubescent. Petals 4 , oblong to oblanceolate, $1.8-2 \times 0.4-0.6 \mathrm{~cm}$, distinctly clawed, obtuse at apex, all with shade of purple throughout, except the 2 middle ones with a yellow blotch at the middle with blue boundary. Stamens 11, unequal, exserted; filaments free, glandular-hairy at base; the outer longer stamens 6, 2-2.5 cm long; anthers grey; the inner shorter stamens 5, 1.5-1.9 cm long; anthers yellow. Ovary linear, $0.9-1.1 \mathrm{~cm}$ long, glandular, pubescent; gynophore c. $1 \mathrm{~cm}$ long, glandular-hairy; style $0.2-0.3 \mathrm{~cm}$ long, glabrous; stigma subcapitate. Capsules narrowly linear, 9-16 $\times$ c. $0.2 \mathrm{~cm}$, straight or slightly curved on maturity, spreading; gynophores 1.5-2 cm long; seeds 42-67, reniform, c. $0.2 \mathrm{~mm}$ in diam. with conspicuously rugose-tuberculate transverse ridges, glabrous, black.

Flowering: December-March; Fruiting: April-May.

Habitat: Wastelands and on roadsides in association with Achyranthes aspera L., Breynia retusa (Dennst.) 

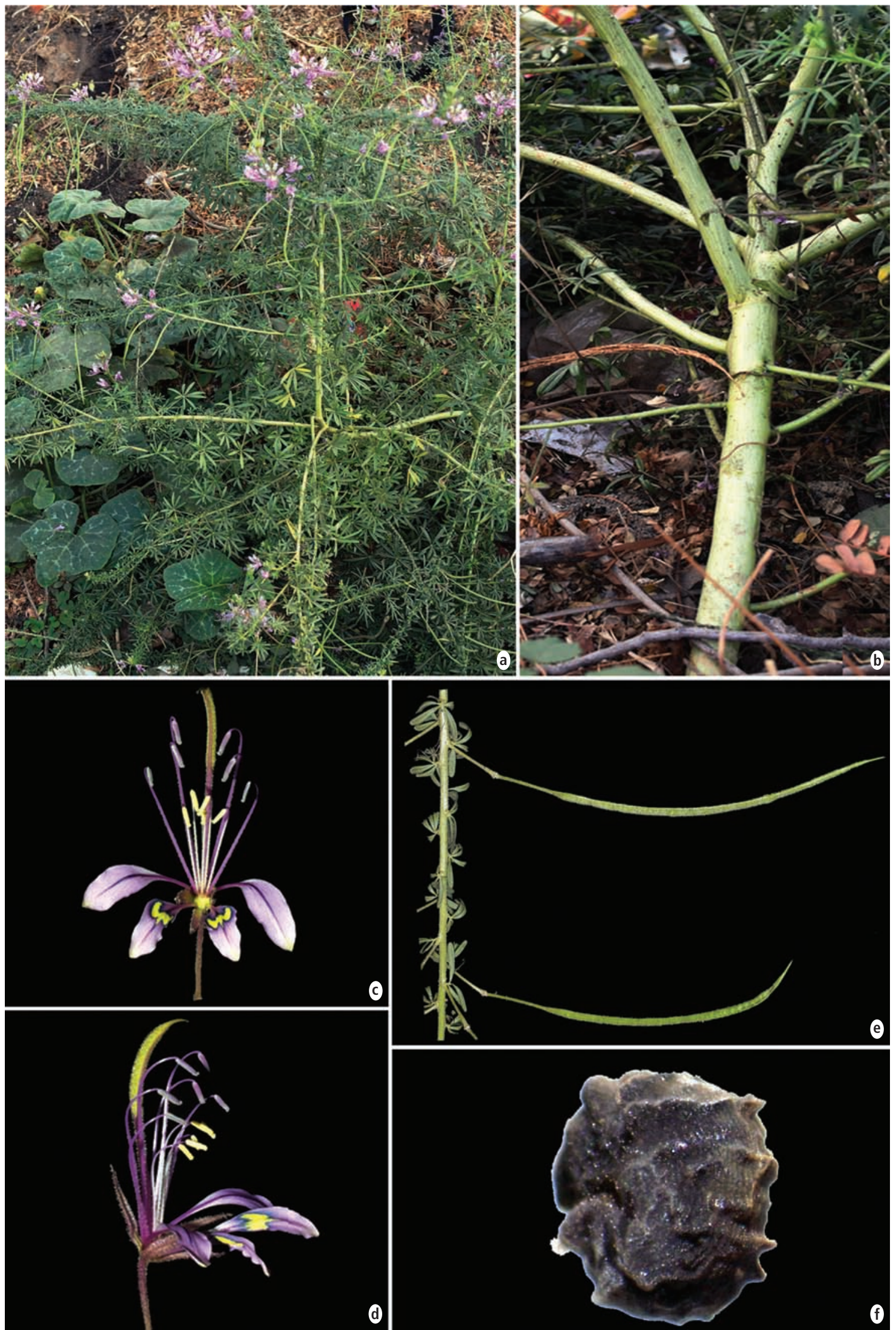

Fig. 1. Cleome hirta (Klotzsch) Oliv.: a. Habit; b. Basal portion of stem; c,d. Front and side views of flower; e. A portion of fruiting-twig; f. Seed. 


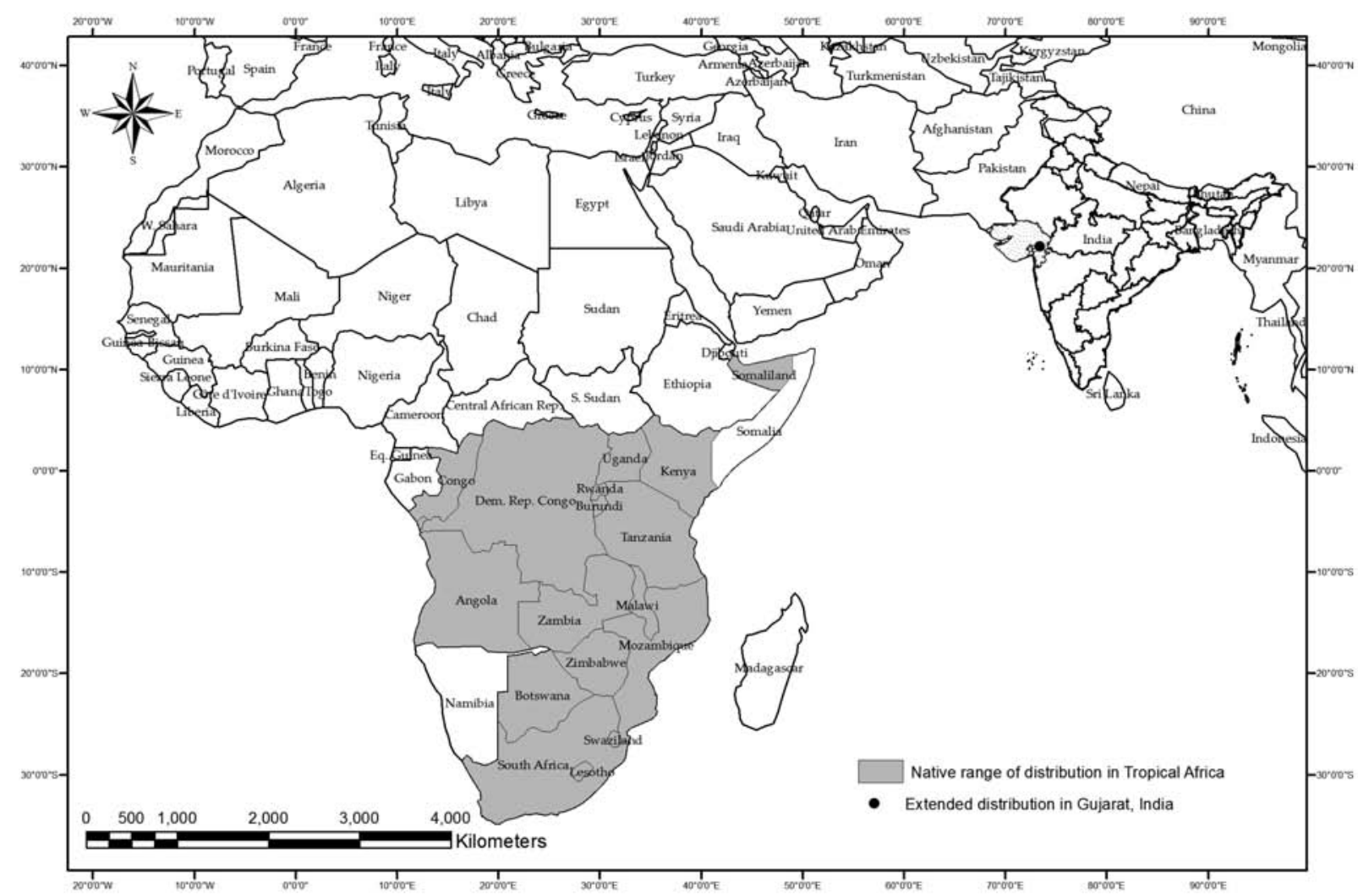

Map. Global distribution of Cleome hirta (Klotzsch) Oliv.

Alston, Cardiospermum halicacabum L., Fagonia cretica L., Ipomoea carnea Jacq. subsp. fistulosa (Mart. ex Choisy) D.F. Austin.

Specimen examined: INDIA, Gujarat, Vadodara district, Faratikui, $22^{\circ} 8^{\prime} 58.48^{\prime \prime} \mathrm{N}, 73^{\circ} 22^{\prime} 49.72^{\prime \prime}$ E, 91 m, 29.1.2015, Mital R. Bhatt MB120 (BARO).

Distribution: Indigenous to tropical Africa (Angola, Botswana, Congo, Democratic Republic of the Congo, Kenya, Limpopo Malawi, Mozambique, Mpumalanga, Somalia, Somaliland, South Africa, Tanzania, Uganda, Zambia and Zimbabwe), now in India (Faratikui, Vadodara district, Gujarat). Map

\section{Acknowledgements}

MRB and PSN are thankful to Prof. Sandhya Kiran Garge, the Head, Department of Botany, The Maharaja Sayajirao University, Baroda, for providing necessary laboratory facilities during this work.

\section{Literature Cited}

Inda, L.A., Torrecilla, P., Catalan, P. \& T. RuizZapata 2008. Phylogeny of Cleome L. and its close relatives Podandrogyne Ducke and Polanissia Raf. (Cleomoideae, Cleomaceae) based on analysis of nuclear ITS sequences and morphology. Pl. Syst. \& Evol. 274: 111-126.

Mabberley, D.J. 2008. Mabberley's Plant-Book: A portable dictionary of plants, their classification and uses. Third edition. Cambridge University Press, Cambridge.

Sanchez-Acebo, L. 2005. A phylogenetic study of the New World Cleome (Brassicaceae, Cleomoideae). Ann. Missouri Bot. Gard. 92(2): 179-201.

Santapau, H. 1962. Flora of Saurashtra. Vol. 1 (Ranunculaceae - Rubiaceae). Saurashtra Research Society, Rajkot. pp. 14-20.

Shah, G.L. 1978. Flora of Gujarat. Part 1. Sardar Patel University, Vallabh Vidyanagar. pp. 66-75.

Sundararaghavan, R. 1993. Capparaceae. In: Sharma, B.D. \& Balakrishnan, N.P. (eds.), Flora of India. Vol. 2. Botanical Survey of India, Calcutta. pp. 248-335.

Received: 3.4 .2017

Revised and Accepted: 12.6.2017 